\title{
Differences of Opinion among Students of Czech Higher Education Institutions on the Competences of Accountants Required by the Labour Market
}

\author{
Kateřina Berková $^{1, *}$, Andrea Kubišová ${ }^{2}$, Dana Kolářová ${ }^{3}$ \\ ${ }^{1}$ College of Polytechnics Jihlava, Department of Economics, Jihlava, 586 01, Czech Republic \\ ${ }^{2}$ College of Polytechnics Jihlava, Department of Mathematics, Jihlava, 586 01, Czech Republic \\ ${ }^{3}$ Institute of Hospitality Management, Prague 181 00, Czech Republic
}

Received July 14, 2021; Revised September 1, 2021; Accepted September 21, 2021

\section{Cite This Paper in the following Citation Styles}

(a): [1] Kateřina Berková, Andrea Kubišová, Dana Kolářvóa , "Differences of Opinion among Students of Czech Higher Education Institutions on the Competences of Accountants Required by the Labour Market," Universal Journal of Accounting and Finance, Vol. 9, No. 5, pp. 1009 - 1018, 2021. DOI: 10.13189/ujaf.2021.090511.

(b): Kateřina Berková, Andrea Kubišová, Dana Kolárová (2021). Differences of Opinion among Students of Czech Higher Education Institutions on the Competences of Accountants Required by the Labour Market. Universal Journal of Accounting and Finance, 9(5), 1009 - 1018. DOI: 10.13189/ujaf.2021.090511.

Copyright $\bigcirc 2021$ by authors, all rights reserved. Authors agree that this article remains permanently open access under the terms of the Creative Commons Attribution License 4.0 International License

\begin{abstract}
The aim of the study is to examine the differences of opinion among students $(n=74)$ of Czech higher economic education institutions on the requirements of employers for accountants. Data collection was conducted in 2020 using a questionnaire. The data were analysed by Pearson correlation coefficient to look for relations between variables (i.e., gender, type of higher education institution, popularity of accounting, professional interest, quality of school training, importance of competencies). Gender differences and differences between students in terms of type of institution were tested by Mann-Whitney U-test. It was found that there is a need to strengthen students' awareness of the requirements of employers in the Czech and international labour market in the field of accounting practice. Gender, type of institution and popularity of the accounting subject have an influence on the perception of the importance of competences for accounting practice. Differences were found at the level of soft skills, namely in the case of effective communication and responsibility. The findings suggest the need to strengthen practical training in terms of time allocation, involvement of experts from the field, internships, as well as the modernization of the curriculum.
\end{abstract}

Keywords Soft Skills, Expertise, Accounting Profession, Accounting, Labour Market, Student Attitudes, Higher Education Institution

\section{Introduction}

Economic reality has evolved considerably and the demands of the labour market are changing significantly. There are higher demands from society, which is mainly due to innovation and the development of digital technologies [1]. This, of course, goes hand in hand with the development of the necessary skills in future graduates entering the labour market [2]. Employers not only require professional competences, but also soft skills are coming to the fore [3], [4]. Different definitions of soft skills can be found in the literature. For example, soft skills are defined by the authors [3], [4] as competences that every employee should possess, regardless of occupation. These are, for example, communication skills, presentation skills, reliability, responsibility, independence, time management etc. Professional competences are defined in close relation to the respective profession. In terms of accounting positions, the most common are information and language literacy, invoicing, financial statement and reporting [5], [6].

The power of soft skills in the labour market is supported by the finding that they positively contribute to an increase in employee wages up to double the amount 
[7]. There are various studies verifying whether soft skills are more essential for employers than expertise is [8], [9]. Research in Australia and New Zealand has looked at content analysis of skills specified in job advertisements. The results show that personal and interpersonal skills were the most frequently mentioned requirements for tax accountant positions. The authors recommend that the development of these skills should also be given attention in practical training at higher education institution [4]. Among soft skills, willingness to learn and time management are also important for employers [9]. Furthermore, research significantly shows that employers value communication, analytical and time management skills the most and prefer a positive approach to employment. These international findings also coincide with the requirements of employers in the Czech labour market at the level of accounting positions [10]. This knowledge has influenced accounting education in various higher education institutions and also the IFAC member bodies [11].

Modern professional accountants need both hard and soft skills. Therefore, along with the development of communication skills, working and searching skills including information analysis, self-education, teamwork, etc., the acquisition of professional competencies should take place [12]. From the perspective of hard competencies, IFRS is emphasized in corporate practice [13]. Also, modern disciplines such as environmental accounting are moving forward and are more frequently mentioned in the field [14]. However, it is important that future accountants are trained with the most up-to-date ICT skills that employers use with regard to relevant accounting software [15].

In order to meet employers' demand, school training for accounting practice in different job roles needs to be adapted to their requirements. A study [16] found problems in the professional preparedness of students and also problems of accounting education that is not in line with global trends. Weaknesses were identified in the development of critical thinking, leading to the need to modify the curriculum and change teaching strategies to promote the employability of new graduates in the accounting job market. Similar research has also been carried out at the level of soft skills. Internationally, a problem has been identified in relation to interpersonal and communication skills [11]. Gaps were further identified in the proficiency and skill of using English language in the accounting profession [17]. Higher education institutions need to respond to such limitations primarily by innovating the educational system to improve the quality of students' preparation for practice [18] by responding to research findings in the form of upgrading courses, incorporating modern technology into teaching, extra-curricular courses that support the required competencies, and involving experts from the field [19].

It is also important how university students perceive the importance of soft skills and expertise for the accounting profession. This understanding is crucial for preparation for practice, as students' perceptions of their dream profession influence their future development. The above-mentioned topic is of interest in several studies [5], [8]. It has been found that students' awareness of the demands of professions is low. Those studies have shown that students rate creativity, communication, interpersonal skills, decision making and problem solving as not important for accounting practice, and students place more emphasis on expertise. Another study examined students' confidence in relation to their readiness for accounting practice. The research showed that students are insecure and again have less awareness of employers' requirements [20]. This is also supported by a study that demonstrates that students agree on the need to acquire strategic skills to work in accounting positions [21]. The amount of substantive content implemented is not sufficient in the opinion of the students. In particular, they expect more practical classes, including extended internships. They point out that more attention should be paid to case studies and problem solving. They are also interested in more activities involving bookkeeping using software. At the same time, most students plan to extend the knowledge acquired during their undergraduate studies and pursue a professional accounting career. There are concerns that the current curriculum does not meet the educational needs of future accountants in terms of sustainability [22]. If the quality of school training is understood from the student's perspective as a measure of the student's alignment with the requirements of the labour market [12], then the above research suggests that students are not satisfied with the quality of school training for accounting practice [23]. The question is whether the evaluation of the importance of competences for accounting practice depends on the students' evaluation of the quality of their school training. This study seeks to answer this question, among others. Thus, it is necessary to encourage higher education institutions to engage in the path of multidisciplinary education and to rethink their pedagogical models in view of future professional challenges. There is a need to introduce interdisciplinary courses, courses that promote soft skills and integrated student development [21].

The question of how higher education institution students perceive the importance of competences for the performance of future profession is currently widely discussed. Factors that may influence students' perceptions of their importance, such as field of study, mode of instruction, socioeconomic factors [24], type of higher education institution, and gender [25], are being explored. Hence, this study is also oriented in this direction, i.e., what factors can influence the perception of the importance of soft skills and expertise for the accounting profession.

There is research showing that gender has an impact on 
fear, apprehension and anxiety about studies or future careers [26]. This affects academic performance in a given subject [27] and may also influence perceptions of the competencies needed for working in the field.

\section{Objectives and Hypotheses}

The aim of the research is to find out the perception of higher education students of undergraduate economics majors on the importance of soft skills and expertise for the accounting profession. The study aims to identify differences in students' views on the requirements of the labour market by gender, type of higher education institution, professional interest in accounting, popularity of accounting and by perception of the quality of school training for the accounting profession, while finding correlations between the variables. Based on the findings, recommendations will be proposed to effectively prepare students for the accounting profession and increase their awareness of labour market requirements during their studies at higher education institution, taking into account current trends in the national and international labour market. This study is primarily of educational importance. It is important for students to have a realistic understanding of the requirements of employers for the accounting profession. Therefore, it is important to find out what their current awareness is, compare it with current labour market trends with an orientation towards the accounting profession and then propose recommendations with implications for the preparation of graduates for future careers.

The following hypotheses emerge from the objective:

- H1: Perceptions of the importance of technical and soft skills to the accounting profession differ by gender.

- H2: Perceptions of the importance of professional and soft skills to the accounting profession vary by type of higher education institution.

- H3: There is a correlation between students' interest in the accounting profession and their attitudes towards the importance of accounting competence.

- H4: There is a correlation between the popularity of the subject of accounting in school and students' attitudes towards the importance of accounting competence.

- H5: There is a correlation between students' attitudes towards the quality of school preparation for the accounting profession and the importance of accounting competence.

- H6: There is a correlation between the perceived importance of the competencies studied from the students' perspective.

\section{Materials and Methods}

The methodological basis of this research is a study that documents the preparation of Czech higher education students for future economic professions from the perspective of innovations in education [28]. The method and conceptual approach of this research were inspired by several researches. The authors [29] oriented their research on the labour market requirements in the area of preparing students for accounting practice. Another study [8] examined the difference between recent university graduates and employers in the perceived importance of professional and soft skills that employers place on employees.

The sample consists of undergraduate students of Accounting and Finance from the Prague University of Economics and Business and the College of Polytechnics Jihlava in the Czech Republic. The selection of the university and college was conditioned by the choice of two different regions - Vysočina Region and the capital city of Prague in terms of job offer. In the capital city, there is also a greater job offer in the field of accounting compared to the Vysočina Region [30] and students of the Prague University of Economics and Business can already work as accountants during their studies. The choice of the university and college was also conditioned by the fact that they are the largest institutions of economics in the regions of the capital city of Prague and the Vysočina Region. The reason for selecting these institutions was primarily due to the differences that may be evident among students, their mentality and their different perceptions of labour market trends and the demands of current employers. At the same time, however, it was necessary to select the largest economic institutions in both regions because of the job opportunities and also that the students would be competent to answer the questions in the questionnaire. The university and college were included in the research by purposive sampling, as were the 74 students who participated in the research between May and June 2020. The research was conducted on the students' voluntary basis and during the time of the declaration of a state of emergency in the Czech Republic due to COVID-19 and thus the ban on students' personal presence in schools, which is why the sample is not higher. The research sample is described by several characteristics, which are discussed in the following analysis (Table 1). Because the pandemic crisis resulted in lower returns and a smaller research sample, differences between years of study were not analyzed. Therefore, this analysis will be the subject of further research in which the expanding of the sample is anticipated. 
Table 1. Structure of the research sample

\begin{tabular}{|c|c|c|}
\hline Gender & $\begin{array}{c}\text { Absolute } \\
\text { frequency }\end{array}$ & $\begin{array}{c}\text { Relative } \\
\text { frequency (\%) }\end{array}$ \\
\hline Men & & \\
\hline Women & 26 & 35.1 \\
\hline University/college & 48 & 64.9 \\
\hline $\begin{array}{c}\text { Prague University of } \\
\text { Economics and Business }\end{array}$ & 34 & 45.9 \\
\hline $\begin{array}{c}\text { College of Polytechnics Jihlava } \\
\text { Popularity of accounting } \\
\text { among students }\end{array}$ & 40 & 54.1 \\
\hline Yes & 50 & 67.6 \\
\hline No & 24 & 32.4 \\
\hline $\begin{array}{c}\text { Professional interest in } \\
\text { accounting }\end{array}$ & 39 & 52.7 \\
\hline Yes & 35 & 47.3 \\
\hline No & 31 & \\
\hline $\begin{array}{c}\text { Perceptions of the quality of } \\
\text { school training for the } \\
\text { accounting profession }\end{array}$ & & \\
\hline Positive perception & & \\
\hline Negative perception & 35.4 \\
\hline
\end{tabular}

For data collection, quantitative research methods were used, which was based on interviewing through a non-standardized questionnaire and was methodologically inspired by an international study [8]. The survey was conducted online using a web-based questionnaire that was sent to students' email addresses. All sensitive data were anonymized and encrypted. Prior to the actual research, a pre-survey was conducted with a sample with the characteristics of the respondents from the main survey, thus increasing the content validity and reliability of the research instrument.

Table 2. Occurrence of competences in advertisements of Czech companies

\begin{tabular}{|c|c|c|}
\hline Competence & $\begin{array}{c}\text { Absolute } \\
\text { frequency }\end{array}$ & $\begin{array}{c}\text { Percentage of } \\
\text { incidence in total (\%) }\end{array}$ \\
\hline Information literacy & 26 & 59.1 \\
\hline $\begin{array}{c}\text { Language literacy (use of } \\
\text { English language) }\end{array}$ & 20 & 45.5 \\
\hline Invoicing & 16 & 36.4 \\
\hline Financial Statements & 16 & 36.4 \\
\hline Reporting & 11 & 25.0 \\
\hline Audit preparation & 13 & 29.5 \\
\hline Taxing & 15 & 34.1 \\
\hline Payroll processing & 10 & 22.7 \\
\hline Independence & 23 & 52.3 \\
\hline Diligence & 19 & 43.2 \\
\hline Reliability & 16 & 36.4 \\
\hline Responsibility & 13 & 29.5 \\
\hline Cooperation & 6 & 13.6 \\
\hline Effective communication & 8 & 18.2 \\
\hline Flexibility & 7 & 15.9 \\
\hline
\end{tabular}

The importance of soft skills and expertise to the accounting profession was expressed on a five-point Likert scale of 1-5, with higher values indicating greater importance of the competency to the accounting profession. Expertise was defined by the following dimensions: information literacy, language literacy, invoicing, financial statements, reporting, audit preparation, tax preparation, payroll processing. Within the soft skills, the following areas were selected: independence, diligence, reliability, responsibility, cooperation, effective communication, flexibility. The professional and soft skills were selected according to their most frequent occurrence in 40 published advertisements of companies [10] offering this job position in the real time of the research (Table 2) and taking into account international trends in accounting, financial reporting and taxation [11], [17].

Expertise is assessed together as a single competency required of the accounting profession. Soft skills are considered at the level of sub-skills, and this is because research shows that soft skills are gaining importance among employers [8], [9] and therefore there is a need to identify which sub-skills from the soft skills are perceived by students to be important for starting a career in accounting.

Other areas of the questionnaire were aimed at identifying the characteristics of the respondents against which the hypotheses were tested. These were gender, university/college in the region, popularity of the subject of accounting, professional interest in accounting and perception of the quality of school training for the accounting profession. The data were obtained by answering multiple choice questions. Because of the simplicity of the research instrument - the questionnaire the questionnaire is not presented here in full, but the variables that were subsequently assessed are described in detail.

Reliability of the questionnaire was measured by computing the Cronbach's alpha. The questionnaire was evaluated as reliable, as the Cronbach's alpha is 0.667 . The value is between 0 and 1 and acceptable value oscillates to 0.7 .

The original data obtained from the questionnaire survey are of several types. Variables reflecting the descriptive characteristics of the respondents, i.e., gender, type of university/college, professional interest, popularity and perception of the quality of school training for accounting practice are nominal variables and are used as a sorting factor to conduct comparative analyses. The data contain mostly numerical ordinal variables, i.e., students' perceptions of the importance of soft skills and professionalism to the accounting profession are expressed on a five-point Likert scale of 1 to 5. Both types are commonly treated as numerical variables. The importance is described by the arithmetic mean. Since these characteristics do not meet the requirement of 
normality (verified by the Shapiro-Wilk test), but meet the requirement of homogeneity of variances (verified by the Levene test), the Mann-Whitney U test was selected from the two-sample tests to assess the hypotheses $\mathrm{H} 1$ and $\mathrm{H} 2$.

A correlation matrix was constructed to determine the correlation relations between variables in the case of testing hypotheses $\mathrm{H} 3-\mathrm{H} 6$. The tables presented in the Results section show only part of it. The field inside the body of the table always contains the value of Pearson's correlation coefficient $r$, which is usually used for this type of data. Statistical analysis was performed using the program SPSS.

Null hypotheses tested at 5\% significance level:

- $\quad \mathbf{H}_{0-1}$ : There is no gender difference in the perception of the importance of technical and soft skills for the accounting profession.

- $\quad \mathbf{H}_{\mathbf{0 - 2}}$ : Perceptions of the importance of professional and soft skills to the accounting profession do not differ by type of institution of higher education.

- $\mathbf{H}_{0-3}$ : There is no correlation between students' interest in the accounting profession and their attitudes towards the importance of accounting competencies.

- $\quad \mathbf{H}_{0-4}$ : There is no correlation between the popularity of the subject of accounting in school and students' attitudes towards the importance of accounting competencies.

- $\mathbf{H}_{0-5}$ : There is no correlation between students' attitudes towards the quality of school preparation for the accounting profession and the importance of accounting competencies.

- $\quad \mathbf{H}_{0-6}:$ There is no correlation between the perceived importance of the competences studied from the students' perspective.

\section{Results}

\subsection{Descriptive Statistics}

The differences of opinion among students on the importance of soft skills and expertise for the performance of the accounting profession were first determined using descriptive statistics methods, divided according to the characteristics studied. The values were obtained by using arithmetic mean (Table 3). In Table 3, the competencies are indicated in this way: A - Independence; B - Effective Communication; C - Cooperation; D - Reliability; E Diligence; F - Responsibility; G - Flexibility; H Expertise.

At the level of the observed averages, differences in the perceived importance of soft skills and expertise for the accounting profession from a gender perspective are evident. For men, expertise is more important and for women, soft skills are more important, to which they assigned higher values in the range of 1 to 5 in all seven categories.

Table 3. Descriptive statistics - opinion differences by respondent characteristics

\begin{tabular}{|c|c|c|c|c|c|c|c|c|}
\hline \multirow{2}{*}{ Variable } & \multicolumn{8}{|c|}{ Competence } \\
\hline & $A$ & $B$ & $C$ & $D$ & E & $F$ & $G$ & $H$ \\
\hline \multicolumn{9}{|c|}{ Gender } \\
\hline Men & 4.077 & 3.923 & 3.808 & 4.615 & 4.500 & 4.654 & 3.615 & 2.500 \\
\hline Women & 4.500 & 4.125 & 4.042 & 4.729 & 4.688 & 4.708 & 3.813 & 2.292 \\
\hline \multicolumn{9}{|c|}{ University } \\
\hline $\begin{array}{c}\text { Prague University of } \\
\text { Economics and Business }\end{array}$ & 4.265 & 4.324 & 3.971 & 4.735 & 4.647 & 4.706 & 3.706 & 2.471 \\
\hline $\begin{array}{c}\text { College of Polytechnics } \\
\text { Jihlava }\end{array}$ & 4.425 & 3.825 & 3.950 & 4.650 & 4.600 & 4.675 & 3.775 & 2.275 \\
\hline \multicolumn{9}{|c|}{ Popularity of accounting among students } \\
\hline Yes & 4.260 & 3.960 & 3.920 & 4.620 & 4.540 & 4.600 & 3.700 & 2.280 \\
\hline No & 4.542 & 4.250 & 4.042 & 4.833 & 4.792 & 4.875 & 3.833 & 2.542 \\
\hline \multicolumn{9}{|c|}{ Professional interest in accounting } \\
\hline Yes & 4.205 & 4.026 & 4.000 & 4.615 & 4.564 & 4.641 & 3.821 & 2.282 \\
\hline No & 4.514 & 4.086 & 3.914 & 4.771 & 4.686 & 4.743 & 3.657 & 2.457 \\
\hline \multicolumn{9}{|c|}{ Perceptions of the quality of school training for the accounting profession } \\
\hline Positive perception & 4.341 & 4.098 & 4.049 & 4.634 & 4.585 & 4.659 & 3.707 & 2.341 \\
\hline Negative perception & 4.364 & 4.000 & 3.848 & 4.758 & 4.667 & 4.727 & 3.788 & 2.394 \\
\hline
\end{tabular}


Differences of opinion were also found in terms of the focus of the higher education institutions. For the students of the practically oriented College of Polytechnics Jihlava only two soft skills are more important for the accounting profession. They are independence and flexibility. The other soft skills and expertise are more important to students of the Prague University of Economics and Business, who are closer to the requirements of Czech employers (cf. Table 2). The discrepancy may be due to the fact that students of the Prague University of Economics and Business can, to a greater extent, due to their studies in the capital city of Prague, where there are more job opportunities, already work directly in accounting firms or in accounting positions, and thus gain a more accurate understanding of the situation on the labour market in relation to accounting positions, and therefore may perceive these competences as more relevant for practice.

Differences in attitudes towards the importance of accounting competencies were measured by the popularity of the subject of accounting in school among students. Students who liked the subject assigned less importance to all the competencies compared to students who found the subject unpopular in school. In case of occupational interest, the situation developed similarly. Students who would like to pursue accounting professionally assigned higher importance to only two soft skills - flexibility and cooperation. The other soft skills and expertise are given more importance by students who are not interested in pursuing a career in accounting.

Similar differences were also found in terms of students' perceptions of the quality of school preparation for the accounting profession. Those who are satisfied with their school training and perceive it positively, assigned more importance to only two skills, namely effective communication and cooperation. Students who are not satisfied with their school preparation for the accounting profession in practice gave lower importance ratings for the other soft skills (independence, reliability, diligence, responsibility, flexibility) and expertise.

The opinion differences among students in terms of the studied characteristics were further verified at the 5\% significance level.

\subsection{Opinion differences between students by gender and by university/college (hypothesis H1, H2)}

Gender differences in attitudes towards the importance of competencies were analysed using the Mann-Whitney $\mathrm{U}$ test. Differences were further examined by type of university/college. The results are presented in Table 4.

Table 4. Significance of differences between students' attitudes in terms of gender and type of university/college

\begin{tabular}{|c|c|c|}
\hline Competence & $\begin{array}{c}\text { Gender } \\
(\boldsymbol{p})\end{array}$ & $\begin{array}{c}\text { University/college } \\
(\boldsymbol{p})\end{array}$ \\
\hline A-Independence & 0.033 & 0.602 \\
\hline $\begin{array}{c}\text { B-Effective } \\
\text { Communication }\end{array}$ & 0.256 & 0.025 \\
\hline C-Cooperation & 0.324 & 0.839 \\
\hline D-Reliability & 0.379 & 0.423 \\
\hline E-Diligence & 0.426 & 0.543 \\
\hline F-Responsibility & 0.977 & 0.565 \\
\hline G-Flexibility & 0.342 & 0.757 \\
\hline H-Expertise & 0.229 & 0.242 \\
\hline
\end{tabular}

Statistically significant gender differences were found only in the case of soft skills - independence. Women perceive this competence as more important for the accounting field than men. No significant gender differences were found in other competences.

At $95 \%$ significance level, the researchers reject the hypothesis $\mathrm{H}_{0-1}$ in the case of soft autonomy competence.

Statistically significant differences between the attitudes of students of the bachelor's degree programme in economics were also found in terms of the type of higher education institution of economics. A significant difference was found in the case of perceived importance of soft skills - effective communication. This competence is perceived as more important for the accounting profession by students of the Prague University of Economics and Business. No statistically significant differences were found in other competences according to the type of the higher education institution.

At $95 \%$ significance, the researchers reject the $\mathrm{H}_{0-2}$ hypothesis for the soft skill of effective communication.

4.3 Correlation analysis of the variables under study (hypotheses $\mathrm{H} 3-\mathrm{H} 6$ )

Pearson correlation coefficient $r$ was first used to find correlations between the importance of competencies and the following variables: professional interest in accounting, popularity of the subject of accounting at school and perception of the quality of school preparation for the accounting profession. Statistical analysis was performed at $95 \%$ confidence level. The results are presented in Table 5. 
Table 5. Correlation matrix - relations among the importance of competences, professional interest, popularity of the accounting subject and perceived quality of school training for accounting practice

\begin{tabular}{|c|c|c|c|c|c|c|c|c|c|}
\hline & & $A$ & $B$ & $C$ & $D$ & $E$ & $F$ & $G$ & $H$ \\
\hline \multirow{2}{*}{ Professional interest } & Pearson's $r$ & -0.198 & -0.032 & 0.052 & -0.150 & -0.100 & -0.090 & 0.089 & -0.127 \\
\hline & $p$ & 0.090 & 0.785 & 0.662 & 0.201 & 0.398 & 0.448 & 0.451 & 0.282 \\
\hline \multirow{2}{*}{ Popularity } & Pearson's $r$ & -0.169 & -0.146 & -0.069 & -0.193 & -0.194 & -0.227 & -0.068 & -0.178 \\
\hline & $p$ & 0.149 & 0.214 & 0.561 & 0.100 & 0.098 & 0.052 & 0.564 & 0.130 \\
\hline \multirow{2}{*}{$\begin{array}{l}\text { Quality of school } \\
\text { preparation for } \\
\text { practice }\end{array}$} & Pearson's $r$ & -0.014 & 0.052 & 0.120 & -0.118 & -0.066 & -0.060 & -0.044 & -0.038 \\
\hline & $p$ & 0.905 & 0.658 & 0.308 & 0.315 & 0.574 & 0.611 & 0.712 & 0.749 \\
\hline
\end{tabular}

Table 6. Correlation matrix - relations among the importance of soft skills and expertise to accounting practice

\begin{tabular}{|c|c|c|c|c|c|c|c|c|c|}
\hline & & A & B & $\mathrm{C}$ & $\mathrm{D}$ & $\mathrm{E}$ & $\mathrm{F}$ & G & $\mathrm{H}$ \\
\hline \multirow{2}{*}{$\begin{array}{c}\mathrm{A} \\
\text { Independence }\end{array}$} & Pearson's $r$ & - & & & & & & & \\
\hline & $p$ & - & & & & & & & \\
\hline \multirow{2}{*}{$\begin{array}{c}\text { B } \\
\text { Effective } \\
\text { Communication }\end{array}$} & Pearson's $r$ & 0.329 & - & & & & & & \\
\hline & $p$ & 0.004 & - & & & & & & \\
\hline \multirow{2}{*}{$\begin{array}{c}\text { C } \\
\text { Cooperation }\end{array}$} & Pearson's $r$ & 0.273 & 0.705 & - & & & & & \\
\hline & $p$ & 0.019 & $<.001$ & - & & & & & \\
\hline \multirow{2}{*}{$\begin{array}{c}\text { D } \\
\text { Reliability }\end{array}$} & Pearson's $r$ & 0.606 & 0.400 & 0.285 & - & & & & \\
\hline & $p$ & $<.001$ & $<.001$ & 0.014 & - & & & & \\
\hline \multirow{2}{*}{$\begin{array}{c}\text { E } \\
\text { Diligence }\end{array}$} & Pearson's $r$ & 0.480 & 0.538 & 0.371 & 0.699 & - & & & \\
\hline & $p$ & $<.001$ & $<.001$ & 0.001 & $<.001$ & - & & & \\
\hline \multirow{2}{*}{$\begin{array}{c}\mathrm{F} \\
\text { Responsibility }\end{array}$} & Pearson's $r$ & 0.553 & 0.468 & 0.375 & 0.774 & 0.637 & - & & \\
\hline & $p$ & $<.001$ & $<.001$ & $<.001$ & $<.001$ & $<.001$ & - & & \\
\hline \multirow{2}{*}{$\begin{array}{c}\mathrm{G} \\
\text { Flexibility }\end{array}$} & Pearson's $r$ & 0.354 & 0.286 & 0.342 & 0.202 & 0.238 & 0.210 & - & \\
\hline & $p$ & 0.002 & 0.013 & 0.003 & 0.084 & 0.041 & 0.072 & - & \\
\hline \multirow{2}{*}{$\begin{array}{c}\mathrm{H} \\
\text { Expertise }\end{array}$} & Pearson's $r$ & -0.163 & -0.052 & -0.092 & -0.137 & -0.154 & -0.056 & -0.173 & - \\
\hline & $p$ & 0.164 & 0.660 & 0.434 & 0.246 & 0.190 & 0.638 & 0.141 & - \\
\hline
\end{tabular}

The correlation analysis shows that the perception of the importance of the competences needed to practice the accounting profession is significantly related to the popularity of the accounting subject during the studies. This statistical significance was detected for the soft skill competency of responsibility $(p=0.052)$ and a negative relation was also identified. Students who do not like the subject of accounting perceive responsibility as more important for accounting practice. However, the correlation relation is not strong $(r=-0.227)$.

At $95 \%$ level of reliability, the researchers reject the hypothesis $\mathrm{H}_{0-4}$ in the case of soft skill responsibility.

Significant correlations were not found between students' perceptions of the importance of competencies and their professional interest in accounting. Furthermore, there was no correlation between students' perceptions of the importance of competencies and their perceptions of the quality of school preparation for accounting practice.

At $95 \%$ level of significance, the researchers do not reject the hypotheses $\mathrm{H}_{0-3}$ and $\mathrm{H}_{0-5}$.

Using Pearson's correlation coefficient $r$, the hypothesis
$\mathrm{H}_{0-6}$ was tested at the 5\% significance level in order to determine which pairs of competencies are rated similarly and differently by students in terms of their importance for accounting practice. The results are shown in Table 6 . Significant similarity in importance ratings was not demonstrated only for the following pairs of soft skills: reliability-flexibility (D-G); responsibility-flexibility (F-G). For the other pairs of soft skills, it was found at the 95\% significance level that students rated their importance for accounting practice similarly. The strongest relation was found for the pair reliability - responsibility (77.4\%) and for the pair effective communication - cooperation $(70.5 \%)$. The expertise required for accounting practice is not correlated with any of the soft skills.

At $95 \%$ level of reliability, the researchers reject the hypothesis $\mathrm{H}_{0-6}$ in the case of soft skills, in exception of pairs: reliability - flexibility, responsibility - flexibility.

\section{Discussion}

The study focused on exploring the views among Czech 
students of bachelor's degree programmes in economics on the importance of soft skills and expertise for the accounting profession. Several significant results were identified in terms of opinion differences examined by gender, type of higher education institution, professional interest in accounting, popularity of accounting, and perceptions of the quality of school preparation for the accounting profession.

The students of the higher economic education institutions, which differ in size, location of their headquarters and especially in their practical focus, are closer to the real requirements of Czech employers for accounting jobs [10], cf. Table 2. Czech employers demand from applicants and employees mainly independence, diligence, responsibility, reliability, whereas students rated these skills as less important for accounting practice. These soft skills are also significantly correlated with each other. Students rated the importance of the competencies similarly. This similarity was found for each pair of soft skills except for the following: reliability-flexibility; responsibility-flexibility. Also, international studies highlight the increase in the development of interpersonal skills already during school training to start future accounting careers [4], [9], [11]. It shows that soft skills are gaining importance not only on the Czech but also on the international labour market [2], [8], [10].

Expertise is perceived by students as less important for accounting practice compared to soft competencies. In this context, there is a greater disconnection between students and real accounting practice, as modern professional accountants need both hard and soft skills. In terms of professional competencies, IFRSs are emphasized in corporate practice [13]. Future accountants need to be equipped with ICT skills with respect to relevant accounting software [15]. Problems also persist in the professional field at the level of school training of students to practice the accounting profession. The gaps are in the development of critical thinking skills [16].

In terms of the differences between students' opinions according to the higher education institution, significant differences were found in the case of the soft skill of effective communication. This competence is perceived more significantly by students of the Prague University of Economics and Business for the accounting profession. This discrepancy may be due to the greater involvement of students of this university in job opportunities in the field of accounting already during their studies due to the opportunity to study directly in the capital of the Czech Republic. The College of Polytechnics Jihlava is a regional university which is practically oriented and its students do internships during their studies, but it is located in a smaller city which does not offer the same range of job opportunities as Prague. The discrepancy between the perceived importance of effective communication among students of the Czech higher education institutions studied may also be due to the fact that the didactic portfolio of the Prague University of Economics and Business is dominated by educational forms and subjects that promote teamwork, communication and presentation skills [31]. This is the direction in which the university's vision in the pedagogical field is heading [32], i.e., for example it respects international trends in the field of education [19].

For the soft skill of responsibility, a relation was found with the popularity of the subject of accounting. Students who do not like the subject of accounting perceive responsibility as more important for accounting practice. Popularity is negatively related to anxiety or apprehension about studying the subject. Concerns affect students' academic success and performance [26], [27]. Attitudes of students who dislike accounting may be related to being more aware than students who like the subject because they do not experience negative feelings about studying.

The study found that there are gender differences among students in the context of their perception of the importance of competencies for accounting practice, cf. [25]. This study found significant gender differences for the soft skill of independence. Women perceive this competence as more important for the accounting profession compared to men. Men, in general, attributed the greatest importance to the expertise.

With respect to the research sample, no significant association was found between the importance of skills for accounting practice and professional interest in the field, or the perception of the quality of school training for practice. We attribute this result primarily to the structure and size of the research sample, as it is inconsistent with some international studies that have also examined the quality of school training in the context of the importance of competencies for accounting practice. In general, however, students are not satisfied with the quality of school preparation for accounting practice [12] and, in particular, they lack strategic skills for working in accounting positions [21], [23].

The limitation of this empirical study is the sample size and therefore its structure. Since the results were not consistent with international studies in some respects, the sample will need to be expanded beyond the higher education institutions surveyed to include a wider range of economically oriented institutions that prepare students for careers as modern professional accountants. It will also be necessary to analyse differences in student responses in terms of year of study. It will be interesting to analyse the expectations of the business world from accounting education at universities and other higher education institutions, as there may be differences in the concept of the study setting and the requirements of employers. These two pillars must undoubtedly meet. However, in practice there are problems in this respect [1]. 


\section{Conclusions}

The aim of the study was to identify differences in opinion between students of two economically oriented higher education institutions in the Czech Republic on the requirements of employers for accountants. The main findings include the need to strengthen students' awareness of the requirements of employers in the Czech and international labour markets in the field of accounting practice. Furthermore, it will be necessary to strengthen practical training in terms of time allocation, involvement of experts from the field, internships, but also to modernize the curriculum. It will be necessary to incorporate methods and forms supporting the development of interpersonal skills and soft skills into the didactic portfolio in a non-forceful way. In the future, the research will focus on the implementation of these recommendations and the effects of these measures on the development of the target competences.

\section{Acknowledgements}

This research was supported by the College of Polytechnics Jihlava, under Grant no. 1170/10/2135 "Research into the need and availability of a visualization web application for the development of accounting thinking in an interactive environment".

\section{REFERENCES}

[1] N. Akbulaev, I. Mammadov, S. Shahbazli. Accounting education in the universities and structuring according to the expectations of the business world, Universal Journal of Accounting and Finance, Vol. 9, No. 1, 130-137, 2021. DOI: 10.13189/ujaf.2021.090114

[2] L.G. Rudenkol, A.A. Larionova, N.A. Zaitseva, O.N. Kostryukova, E.V. Bykasova, R.Z. Garifullina, F. Safin. Conceptual Model of Training Personnel for Small Business Services in the Digital Economy, Modern Journal of Language Teaching Methods, Vol. 8, No. 5, 283-296, 2018.

[3] E.T. Pereira, M. Vilas-Boas, C.C. Rebelo. Graduates' skills and employability: the view of students from different European countries, Higher Education Skills and Work-based Learning, Vol. 9, No. 4, 758-774, 2019. DOI: https://doi.org/10.1108/HESWBL-10-2018-0098.

[4] L.M. Tan, F. Laswad. Key employability skills required of tax accountants, Journal of the Australasian Tax Teachers Association, Vol. 14, No. 1, 211-239, 2019.

[5] M. Kirstein, S. Coetzee, A. Schmulian. Differences in accounting students' perceptions of their development of professional skills A South African case, Higher Education Skills and Work-based Learning, Vol. 9, No. 1, 41-59, 2019.
[6] K. Barac, K. Plant, R. Kunz, M. Kirstein. Generic skill profiles of future accountants and auditors - moving beyond attributes, Higher Education Skills and Work-Based Learning, unnumbered, 2020. DOI: 10.1108/HESWBL-08-2020-0180.

[7] L. Borghans, B.T. Weel, B.A. Weinberg. People People: Social Capital and the Labor-market Outcomes of Underrepresented Groups. Working paper No. 11985. Massachusetts Avenue: Cambridge, 2006.

[8] A. Rizwan, A. Demirbas, N.A.S. Hafiz, U. Manzoor. Analysis of Perception Gap between Employers and Fresh Engineering Graduates about Employability Skills: A Case Study of Pakistan, International Journal of Engineering Education, Vol. 34, No. 1, 248-255, 2018.

[9] F. Fernandez, H.C. Liu. Examining Relationships between Soft Skills and Occupational Outcomes among U.S. Adults with-and without-university Degrees, Journal of Education and Work, Vol. 32, No. 8, 650-664, 2019. DOI: https://doi.org/10.1080/13639080.2019.1697802.

[10] K. Berková, M. Hnízdilová. Requirements of Czech Employers for the Accounting Profession, Proceedings of the 12th Annual International Scientific Conference COMPETITION, College of Polytechnics Jihlava, 21-29, 2020.

[11] Y. Mameche, M.A. Omri, N. Hassine. Compliance of Accounting Education Programs with International Accounting Education Standards: The Case of IES 3 in Tunisia, Eurasian Journal of Educational Research, Vol. 85, 225-252, 2020. DOI:https://doi.org/10.14689/ejer.2020.85 .11.

[12] G. Dubtsov, G. Dubtsova, A. Vasiucova, I. Kusova, T. Tulyakova. Provision of Continuity of the Training Process for Food Enterprises, 10th International Conference on Education and New Learning Technologies (EDULEARN), Palma, Spain, 9934-9938, 2018.

[13] L. Vallišová, L. Dvořáková. Implementation of international financial accounting standards from the perspective of companies in the Czech Republic, Economic Annals-XXI, Vol. 167, No. 9-10, 70-74, 2018. DOI: https://doi.org/10.21003/ea.V167-14.

[14] L. Vallišová, M. Černá, J. Hinke. Implementation of sustainability aspects in the financial reporting system: an environmental accounting standard, Economic Annals-XXI, Vol. 173, No. 9-10, 55-59, 2018. DOI: https://doi.org/10.21 003/ea.V173-09.

[15] M. Osmani, N. Hindi, V. Weerakkody. Incorporating Information Communication Technology Skills in Accounting Education, International Journal of Information and Communication Technology Education, Vol. 16, No. 4, 100-110, 2020. DOI: 10.4018/IJICTE.2020100107.

[16] S. Asonitou, T. Hassall. Which Skills and Competences to Develop in Accountants in a Country in Crisis? International Journal of Management Education, Vol. 17, No. 3, unnumbered, 2019. DOI: https://doi.org/10.1016/j.ij me.2019.100308.

[17] Y.M. Lim, T.H. Lee, C.S. Yap, C.C. Ling. Employability Skills, Personal Qualities, and Early Employment Problems of Entry-level Auditors: Perspectives from Employers, Lecturers, Auditors, and Students, Journal of Education for 
Business, Vol. 91, No. 4, 185-192, 2016. DOI: https://doi.org/10.1080/08832323.2016.1153998.

[18] T. Moore, J. Morton. The Myth of Job Readiness? Written Communication, Employability, and the 'Skills Gap' in Higher Education, Studies in Higher Education, Vol. 42, No. 3, 591-609, 2017. DOI: https://doi.org/10.1080/03075079. 2015.1067602 .

[19] B.S. Roberts, E.P. Roberts, W. Brachvogel, A.B. Stein. Practice management curricular changes may lead to enhanced preparedness for practice, Journal of Dental Education, Vol. 84, No. 8, 887-894, 2020. DOI: https://doi.org/10.1002/jdd.12136.

[20] G.C. Silva, C.A. Pereira. Expectation of accounting graduates in relation to the labor market, Revista Ambiente Contabil, Vol. 12, No. 2, 254-278, 2020. DOI: 10.21680/2176-9036.2020v12n2ID18594

[21] R.J. da Silva, R. Tommasetti, M.Z. Gomes, M.A.D. Macedo. Accountants' IT responsibilities and competencies from a student perspective, Higher Education Skills and Work-Based Learning, unnumbered, 2020. DOI: 10.1108/HESWBL-02-2020-0028.

[22] H. Al-Hazaima, M. Low, U. Sharma. Perceptions of salient stakeholders on the integration of sustainability education into the accounting curriculum: a Jordanian study, Meditari Accountancy Research, unnumbered, 2021. DOI: 10.1108/MEDAR-02-2020-0708

[23] E. Spigarska, G. Bucior, Kujawski, J. Preferences of the Students of Post-Secondary High Scholls with Economic Profiles and the Quality of Financial Accounting Teaching, 11th Annual International Conference of Education, Research and Innovation (ICERI), Seville, Spain, 1893-1899, 2018.

[24] A. Khayati, D.L. Ariail. Business students' perceptions of faculty attributes: a two-country cross-cultural comparison, Accounting Education, Vol. 29, No. 2, 153-176, 2020. DOI: $10.1080 / 09639284.2020 .1719424$.
[25] M.M. Al Moaleem, M.A. Shubayr, M.K. Aldowsari, M.M. Al-Ahmari, N.M. Al Ahmari, A.A. Alshadidi. Gender Comparison of Students' Perception of Educational Environment using DREEM Inventory, College of Dentistry, Jazan University, Open Dentistry Journal, Vol. 14, 641-649, 2020. DOI: 10.2174/1874210602014010641.

[26] M. Loureiro, N. Loureiro, R. Silva. Differences of Gender in Oral and Written Communication Apprehension of University Students, Education Sciences, Vol. 10, No. 12, unnumbered, 2020. DOI: 10.3390/educsci10120379.

[27] C. Miglietti. Student performance in accounting courses: Do bonus points motivate performance? Journal of Education for Business, 2020. DOI: 10.1080/08832323.20 20.1812486 .

[28] K. Berková, P. Krpálek, K. Krpálková Krelová Future Economic Professionals: Development of Practical Skills and Competencies in Higher Education from the Point of View of International Employers, Economic Annals-XXI, Vol. 176, No. 3-4, 91-98, 2019. DOI: https://doi.org/10.21003/ea.V176-09.

[29] Y.H. Zhao, D.M. Gao. Research on Training Mode of Accounting Personnel in the Demand of Professional Competence, International Conference on Education, Management and Computer Science 2016. Shenyang, PEOPLES R CHINA, 1172-1176, 2016.

[30] Český statistický úrad [Czech Statistical Office], Online available from https://www.czso.cz/csu/czso/statistik_prof ese_mrs.

[31] P. Krpálek, K. Krpálková Krelová, K. Possibilities for Developing Business Potential in Economic Education. Examples of Implementation in Slovakia and the Czech Republic, Economics \& Sociology, Vol. 9, No. 4, 119-133, 2016. DOI: $10.14254 / 2071-789 X .2016 / 9-4 / 7$.

[32] Prague University of Economics and Business, Online available from https://insis.vse.cz/. 